\title{
Ethylene Production and Influence of Silver Thiosulfate on Ethylene Sensitivity of Cut Evergreens
}

\author{
Dwight R. Tingley ${ }^{1}$ and Timothy A. Prince ${ }^{2}$ \\ Department of Horticulture, Ohio Agricultural Research and \\ Development Center, The Ohio State University, Columbus, OH 43210 \\ Additional index words. Abies alba, Abies balsamea, Abies procera, Calocedrus \\ decurrens, Chamaecyparis lawsoniana, Juniperus scopulorum, Juniperus virginiana, \\ Picea abies, Pinus resinosa, Pinus strobus, Pinus sylvestris, Paxistima myrsinites, \\ Pseudotsuga menziesii, Sequoia sempervirens, Thuja occidentalis, Tsuga canadensis, \\ postharvest handling
}

\begin{abstract}
A survey of 16 cut evergreen species found six clustered groupings of species based on ethylene production at 2 and 21C. Ethylene production (in nanoliters per kilogram of fresh weight per hour) at $21 \mathrm{C}$ ranged from 26 for Juniperus virginiana to 2800 for Sequoia sempervirens. Exposure to 0.1 or $1.0 \mathrm{ppm}$ ethylene for 72 hours at 2C resulted in minor effects on two species, while significantly delaying senescence of Sequoia sempervirens. Silver thiosulfate (STS) pretreatment decreased or increased longevity of six species, but all effects were minor. Longevity of cut evergreens when held in preservative solution ranged from 14 days for Pinus sylvestris to 56 days for Chamaecyparis lawsoniana. Senescence symptoms observed were needle abscission, desiccation, and/or chlorosis.
\end{abstract}

Cut evergreens are commonly used in floral designs, so knowledge of ethylene production and sensitivity of evergreens is desirable. Recommendations for postproduction handling of cut evergreens by florists are currently vague and contradictory (Staby et al., 1982; Sullivan et al., 1980). Most studies have been performed with holly (Ilex sp.), which if extremely sensitive to ethylene and benefits from silver thiosulfate (STS) pretreatment (Joyce et al., 1985; Milbrath and Hartman, 1940, 1942).

Staby et al. (1982) reported that many commonly used cut evergreens produce low or undetectable levels of ethylene. They recommended that evergreens could be stored in the same coolers as ethylene-sensitive cut flowers. Sullivan et al. (1980) recommended that cut evergreens be stored separately from cut flowers, presumably due to high ethylene production..

The objectives of this study were to clarify storage recommendations by determining the ethylene production rates and sensitivities of cut holiday evergreens, as well as the efficacy of an STS treatment in preventing ethylene action and increasing longevity.

Sixteen species of cut evergreens (see Table 1) were obtained from a local wholesale

Received for publication 1 Aug. 1989. Salaries and research support provided by state and federal funds appropriated to the Ohio Agricultural Research and Development Center, The Ohio State Univ. Manuscript no. 227-89. We acknowledge the technical assistance of Maria Cunningham. The cost of publishing this paper was defrayed in part by the payment of page charges. Under postal regulations, this paper therefore must be hereby marked advertisement solely to indicate this fact.

'Undergraduate Student.

${ }^{2}$ Assistant Professor. florist. They were produced in Michigan, North Carolina, or the northwestern UnitedStates. After storage at the wholesale florist at 3 to $4 \mathrm{C}$ for $\approx 6$ weeks, they were transferred to The Ohio State Univ., Columbus, and stored in loosely wrapped polyethylene bags at 2 to $3 \mathrm{C}$ until studies began. This extended storage period approximated commercial procedures. Studies were conducted over 7 weeks, beginning 7 Dec. 1988.

Ethylene production Terminal cuttings (15 $\mathrm{cm}$ long) were cut from evergreen boughs at the start of each study. The number of cuttings per replicate varied between five and 10 , depending on the species (20 to $65 \mathrm{~g}$ fresh weight). Cuttings were placed in 1200 . $\mathrm{ml}$ glass jars equipped with clamp-down glass lids, rubber seals, and sampling ports. Jars were flushed with ethylene-free air for 30 set before being sealed. Jars were then held at 2 or $21 \mathrm{C}$ for 72 or $24 \mathrm{hr}$, respectively. Onemilliliter air samples were taken from each jar at the end of the accumulation period. These samples were analyzed for ethylene content using a gas chromatograph with an alumina-packed column and flame-ionization detector. Two-milliliter air samples from each jar were monitored for $\mathrm{CO}_{2}$ levels using a gas chromatograph with a thermal conductivity detector. Carbon dioxide levels were less than $2 \%$ and $6 \%$ at the end of accumulation for the 2 and $21 \mathrm{C}$ treatments, respectively. Two species were monitored at a time at 4-day intervals.

Species were grouped, using Ward's clustering procedure (Green, 1978), by ethylene production rates at both temperatures (Table 1) by inspection of the cluster dendrogram. Sequoia sempervirens (group 1) was the highest ethylene producer at both temperatures. Ethylene production of $S$. sempervi- rens is comparable to that of banana, mango, and tomato in the moderate ethylene-production class of Kader (1985).

The second group contained only Pseudotsuga menziesii. While having a similar ethylene production rate as $S$. sempervirens at $2 \mathrm{C}$, it showed less response to temperature increase. This species would be categorized into the low ethylene-production class with blueberry, pineapple, and raspberry (Kader, 1985). Cut flowers exhibiting a comparable production rate are Vanda orchids (Akamine, 1963).

The species in groups 3, 4, and 5 had similar ethylene production rates at $2 \mathrm{C}$ but responded differently to an increase in temperature. Group 3 showed the highest, group 4 a moderate, and group 5 the lowest temperature response. Like group 2, ethylene production of groups 3 and 4 at $21 \mathrm{C}$ was comparable to other commodities in the low ethylene-producing class (Kader, 1985). Ethylene production of group 5 at $21 \mathrm{C}$ was comparable to grape, potato, and citrus in the very low ethylene-producing class (Kader, 1985).

Species in group 6 had the lowest ethylene production at both temperatures. Juniperus virginiana cuttings with cones clustered in this group, while cuttings without cones were in group 4. This could have been an artifact from the cone weight or could have been due to greater tissue maturity of cuttings with cones. Ethylene production of group 6 at $21 \mathrm{C}$ was comparable to cherry, grape, leafy vegetables, and most cut flowers in the very low production class (Kader, 1985).

Ethylene sensitivity and STS efficacy. Cuttings were prepared as described earlier. STS treatments were administered by spraying onehalf of the cuttings with STS (2 mM Ag) until run-off, with the control treatments sprayed with deionized water only. When the cuttings had dried, they were sealed in 2400-ml glass jars with glass, clamp-down lids equipped with a rubber serum stopper. Two or three cuttings were placed in each jar, depending on the variety. The jars were injected with $2.4 \mathrm{ml}$ of air containing either $100 \mathrm{ppm}$ or $1000 \mathrm{ppm}$ ethylene to produce final ethylene concentrations of $0.1 \mathrm{ppm}$ or $1.0 \mathrm{ppm}$, respectively. Controls of $0 \mathrm{ppm}$ ethylene contained Purafil in the bottom of the jars to oxidize ethylene produced by the evergreens. All jars were randomly placed in a dark, $2 \mathrm{C}$ cooler for $72 \mathrm{hr}$ of simulated storage. Several hours after ethylene injection, air samples were taken from each jar and analyzed for ethylene content as described earlier. Ethylene levels were maintained within $\pm 10 \%$ of treatment levels after 24, 48, and $72 \mathrm{hr}$. Carbon dioxide levels were determined to be less than $2 \%$ after 72 hr.

After treatment, cuttings from each replicate were transferred to beakers of Floralife (Floralife, Chicago) cut-flower preservative solution prepared with deionized water $(\mathrm{pH}$ 3.6, $9.5 \mathrm{~g} \cdot$ liter $\left.^{-1}\right)$. They were held in a room maintained at 20 to $21 \mathrm{C}, 40 \%$ to $50 \% \mathrm{RH}$, and 4 to $5 \mu \mathrm{mol} \cdot \mathrm{s}^{-1} \cdot \mathrm{m}^{-2}$ from cool-white fluorescent lamps during a 12-hr photoper- 
Table 1. Ethylene production rates (nanoliters per kilogram fresh weight per hour \pm 1 SD) of clustered groups of 16 evergreen species at 2 and $21 \mathrm{C}$.

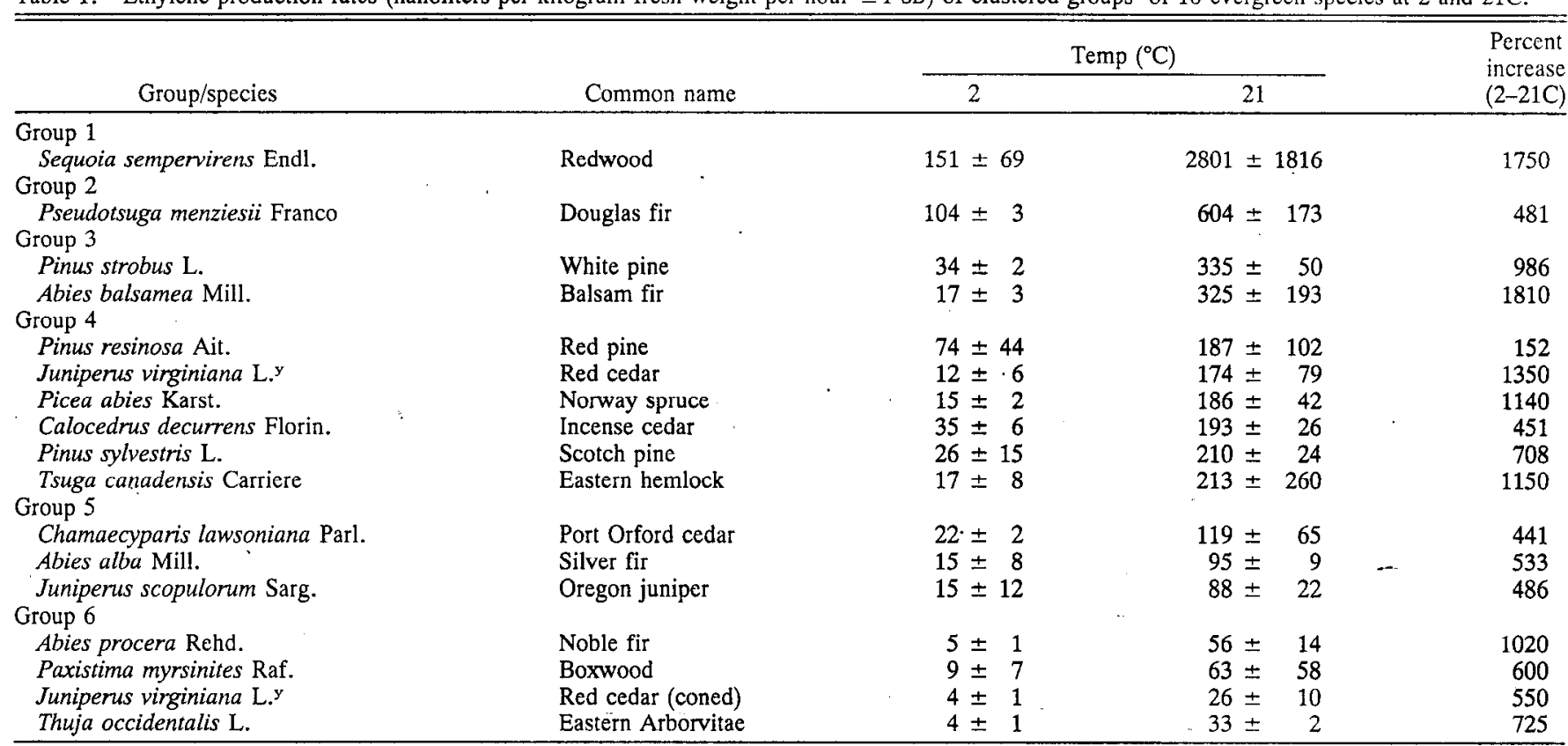

zSpecies grouped using Ward's cluster procedure.

ySupplied to florists with or without cones.

Table 2. Longevity (days) of evergreens that responded to ethylene. ${ }^{z}$

\begin{tabular}{lccc}
\hline \hline $\begin{array}{c}\text { Ethylene } \\
\text { concn } \\
(\mathrm{ppm})\end{array}$ & \multicolumn{3}{c}{ Species } \\
\cline { 2 - 4 } & $\begin{array}{c}\text { Juniperus } \\
\text { scopulorum }\end{array}$ & $\begin{array}{c}\text { Pinus } \\
\text { sylvestris }\end{array}$ & $\begin{array}{c}\text { Sequoia } \\
\text { sempervirens }\end{array}$ \\
0 & 43 & Days & \\
0.1 & 44 & 17 & 29 \\
1.0 & 38 & 15 & 44 \\
F test & & 18 & 43 \\
0 vs. any & NS & & NS \\
0.1 vs. 1.0 & $*$ & $*$ & NS \\
\hline
\end{tabular}

${ }^{2}$ Values are averaged over STS treatment and are means of six replicates.

${ }^{*, * *, N S}$ Ethylene effect significant at $P=0.05$ or 0.001 or nonsignificant, respectively. STS $\times$ ethylene interactions were nonsignificant.

Table 3. Longevity (days) and senescence symptoms of 16 cvergreens in response to STS treatment. ${ }^{z}$

\begin{tabular}{|c|c|c|c|c|}
\hline \multirow[b]{2}{*}{ Species } & \multicolumn{2}{|c|}{$\begin{array}{l}\text { STS conen } \\
(\mathrm{mM} \mathrm{Ag})\end{array}$} & \multirow[b]{2}{*}{$\mathrm{F}$ test $^{\mathrm{y}}$} & \multirow{2}{*}{$\begin{array}{l}\text { Senescence } \\
\text { symptom }\end{array}$} \\
\hline & 0 & 2 & & \\
\hline Abies alba & 39 & 36 & NS & Needle abscission \\
\hline A. balsamea & 23 & 22 & NS & Desiccation \\
\hline A. procera & 32 & 29 & NS & Desiccation \\
\hline Calocedrus decurrens & 16 & 19 & $*$ & Foliagc abscission \\
\hline Chamaecyparis lawsoniana & 56 & 54 & NS & Desiccation \\
\hline Juniperus scopulonum & 42 & 42 & NS & Foliage abscission \\
\hline J. virginiana & 32 & 34 & NS & Desiccation \\
\hline$J$. vinginiana (coned) & 26 & 34 & $* * *$ & Desiccation \\
\hline Picea abies & 20 & 19 & NS & Chlorosis \\
\hline Pinus resinosa & 37 & 43 & NS & Desiccation \\
\hline Pinus strobus & 36 & 39 & NS & Chlorosis \\
\hline Pinus sylvestris & 14 & 18 & $* * *$ & Desiccation \\
\hline Paxistima myrsinites & 30 & 29 & NS & Desiccation \\
\hline Pseudotsuga menziesii & 28 & 20 & $* * *$ & Needle abscission \\
\hline Sequoiä sempervirens & 37 & 41 & NS & Desiccation \\
\hline Thuja occidentalis & 33 & 41 & **** & Desiccation \\
\hline Tsuga canadensis & 26 & 20 & $* *$ & Needle abscission \\
\hline
\end{tabular}

${ }^{2}$ Values are averaged over ethylene treatment and are means of nine replicates.

iod. Ethylene was scrubbed to an average level of $7 \mathrm{ppb}$ in the room. The floral pre- servative solution was replaced when it became cloudy or at 5-day intervals.
Senescence was determined visually as either $50 \%$ chlorosis (half the leaves were yellow, half were green), $50 \%$ needle abscission, or $50 \%$ desiccation (half the leaves dry). The senescence date for each subsample cutting was recorded, and vase life was calculated in days from the start of ethylene treatment until senescence.

Only three species showed significant ethylene effects (Table 2). Pinus sylvestris exhibited a $20 \%$ increase in longevity at 1.0 ppm compared to $0.1 \mathrm{ppm}$ ethylene exposure, while Sequoia sempervirens showed a $50 \%$ increase in longevity after either ethylene treatment. Knee et al. (1988) recently reported that ethylene exposure at low temperatures can actually delay chlorophyll breakdown in citrus; perhaps a similar mechanism was functioning here. Juniperus scopulorum exhibited a decrease in longevity of 6 days $(14 \%)$ at $1.0 \mathrm{ppm}$ relative to $0.1 \mathrm{ppm}$ ethylene. Compared to carnations, which exhibit a $300 \%$ decrease in longevity when exposed to $0.2 \mathrm{ppm}$ ethylene (Nichols, 1968), the detrimental effect of ethylene on $J$. scopulorum is minor.

Six of the 16 species showed a significant response to STS (Table 3), ranging from $\pm 30 \%$ of longevity without STS. For both Pseudotsuga menziesii and Tsuga canadensis, which showed decreased longevity from STS treatment, the predominant senescence symptom was needle abscission. There were no clear differences in senescence symptoms between the control and treated greens, which suggests that Ag toxicity may promote needle abscission. Species that responded positively to STS showed no deleterious ethylene effects, even with no STS pretreatment. This result suggests that $\mathrm{Ag}$ is functioning in some way other than blocking ethylene action. Overall, the observed effects on evergreens 
minor. Therefore, STS treatment does not appear to be useful for commercial use with cut evergreens.

We conclude that evergreens in groups 1 and 2 should be stored seperately from ethylene-sensitive cut flowers. If separate storage is not available, ethylene scrubbing and/ or STS treatment of cut flowers would be advisable.

\section{Literature Cited}

Akamine, E.K. 1963. Ethylene production in fading Vanda orchid blossoms. Science 140:12171218.

Green, P.E. 1978. Analyzing multivariate data.
The Dryden Press, Hensdale, Ill.

Joyce, D.C. M.S. Reid, and R.Y. Evans. 1985. Postharvest handling of Christmas greens. HortScience 20(3):563.

Kader, A.A. 1985. Postharvest biology and technology: An overview. Postharvest technology of horticultural crops. Univ. of California Agr. Special Publ. 3311, Berkeley. p. 3-7.

Knee, M., E. Tsantili, and S.G.S. Hatfield. 1988. Promotion and inhibition by ethylene of chlorophyll degradation in orange fruits. Ann. Appl. Biol. 113:129-135.

Milbrath, J.A. and H. Hartman. 1940. Holly defoliation prevented by 1-napthaleneacetic acid. Science 92(2399):401.

Milbrath, J.A. and H. Hartman. 1942. The cause and control of defoliation in cut holly. Oregon
State Agr. Expt. Sta. Bul. 413.

Nichols, R. 1968. The response of carnations (Dianthus caryophyllus) to ethylene. J. Hort. Sci. 43:335-349.

Staby, G.K., J.W. Kelly, and M.S. Cunningham. 1982. Floral crop storage, p. 239-266. In: D.G Richardson and M. Meheriuk (eds.). Controlled atmospheresfor storage and transport of perishable agricultural commodities. Timber Press, Beaverton, Ore.

Sullivan, G.H., J.L. Robertson, and G.L. Staby. 1980. Postharvest care and handling of fresh flowers and greens. Management for retail tlorists with application to nurseries and garden centers. W.H. Freeman, San Francisco. p. 447474 